\title{
Romanticism Movement in the Novel of Halit Ziya Usakligil Nemide
}

\author{
Ali Algul \\ Faculty of Science and Letters, Department of Turkish Language and Literature, \\ Agri Ibrahim Cecen University, Agri / Turkey \\ Eposta: alialguller@hotmail.com
}

\begin{abstract}
Halite Ziya Usakligil enters the literary world with his novels and stories written in Izmir. He draws attention with his novels such as Sefile, Nemide, Ferdi and Surekâsi. After moving to Istanbul, Halite Ziya attended Servet-i Funun literature. He writes the Turkish novel on the world scale with his success in his novels such as Mai and Siyah, Ask-i Мemnu, in the flow of Servet-i Funun which settled the new Turkish literature. In this study, Nemide, one of the novels of Halite Ziya Usakligil's Izmir period, was examined in terms of romanticism. In the 1830 s as an art stream, with the efforts of Victor Hugo, romanticism became the dominant current in Europe. The current of romanticism, which brought new genres such as drama to literature, prose poetry and historical novels, is seen in Turkish literature in the early 1870s forty and forty-five years after the West. Namik Kemal and Ahmet Mithat Efendi write works according to this movement. Which led to the Turkish novel to the level of advanced countries Halite Ziya, the literary world in 1885 when cycles are made of Western literature in Turkey and the first domestic novels, stories were well written. This ready-to-use environment is able to use the accumulation in its own favor. Halite Ziya, who is studying foreign sources by using the languages he knows, remains influenced by the romanticism movement in Nemide, which is the second place in his novels. Usakligil uses the elements such as escape to nature, yellow color, dilemma, contradiction, pessimism, tuberculosis, emotion, intuition, love, tears, imagination, extraordinary and love of animals, which are among the basic qualities of romanticism in the Nemide novel.
\end{abstract}

Keywords: Romanticism, Turkish novel, Halit Ziya, Nemide

DOI: $10.7176 / \mathrm{JSTR} / 5-4-20$

\section{Halit Ziya Uşaklıgil'in Nemide Romanında Coşumculuk Akımı}

Özet

Halit Ziya Uşaklıgil İzmir'de yazdığı roman ve hikâyeleriyle edebiyat dünyasına girer. Sefile, Nemide, Ferdi ve Şürekâsı gibi romanlarıyla dikkat çeken Halit Ziya, İstanbul'a taşındıktan sonra Servet-i Fünûn edebiyatına katılır. Yeni Türk Edebiyatı'nı yerleştiren Servet-i Fünûn akımı içerisinde, Mai ve Siyah, Aşk-ı Метnu gibi romanlarında gösterdiği biçim ve biçem başarısıyla, dünya ölçeğinde Türk romanını yazar. Bu çalışmada Halit Ziya Uşaklıgil'in İzmir dönemi romanlarından olan Nemide, coşumculuk akımı bakımından irdelenmiştir. Coşumculuk bir sanat akımı olarak 1830'larda, Victor Hugo'nun da çabalarıyla, Avrupa'da hâkim akım olur. Edebiyata dram, mensur şiir, tarihsel roman gibi yeni türler getiren coşumculuk akımı, Türk edebiyatında Batı'dan kırk, kırk beş yıl sonra 1870’lerde görülür. Namık Kemal ve Ahmet Mithat Efendi bu akıma göre yapıtlar yazarlar. Türk romanını ileri ülkeler düzeyine çıkaracak olan Halit Ziya, 1885'lerde edebiyat dünyasına girdiğinde Türkiye'de Batılı edebiyatlardan çevriler yapılmış ve ilk yerli romanlar, öyküler de yazılmış durumdaydı. Bu hazır ortamı, birikimi kendi lehine kullanmasını başarır. Bildiği dillerden yararlanarak yabancı kaynakları da okuyan Halit Ziya, romanları içerisinde ikinci sırada yer alan Nemide'de coşumculuk ekolünün etkisinde kalır. Uşaklıgil coşumculuk akımının temel nitelikleri arasında yer alan doğaya kaçış, sarı renk, ikilem, zıtlık, kötümserlik, verem, duygu, duygusallık, sezgi, aşk, gözyaşı, hayal, olağanüstü ve hayvan sevgisi gibi unsurları Nemide romanında başarılı bir şekilde kullanır.

Anahtar sözcükler: Romantizm, Türk romanı, Halit Ziya, Nemide 


\section{Giriş}

Halit Ziya, Türk romanında kritik bir yerde bulunur. Kendisi 1885-86 y1llarında İzmir'de ilk romanı Sefile'yi yazdığında Türkiye'de roman çevirileri yapılmış, ilk yerli romanlar da yazılmış durumdaydı. Batılı yazın akımlarından da romantizmin bolca örneği verilmiş, realizm akımı yeni yeni girmekteydi. Toplam sekiz roman yazan Halit Ziya'nın ilk dönem romanlarında hazır bulduğu 1880'lerin özellikleri görülür: Aşk, kötü yollara düşen kadınlar, santimantalizm, karamsarlık, yazgıcılık, kız çocuklarının eğitimi, zengin-yoksul karşıtlı̆̆ı, kıskançlık gibi. Hazır bulduğu ortamdan yararlanan Halit Ziya'nın İzmir'de yazdığı romanlar, “Türkiye'de, roman türünün tohumunun tutmaya başladığını gösteren öğelerle yüklüdür.” (Finn, 1984: 123). Çünkü Halit Ziya ilk yapıtlarıyla romana bilinçli bir giriş yapar. Tanpınar da "Bizde asıl romancılık Halit Ziya ile başlar. Namık Kemal, roman nev'ini sadece denemede kaldı”( Tanpınar, 2000: 284) vurgusunu yaparak Halit Ziya'nın Türk edebiyatındaki önemine değinir. Halit Ziya ise kendisinin İstanbul'a geçtikten sonra Türk roman sanatında rol oynamaya başladığını belirtir: “(...) bu sanatta bir gelişme gösterebilmişsem bunu İstanbul'a geldikten sonra Servet-i Fünûn' da ve İkdam'da yapabildim.”(Uşaklıgil, 1964: 631). Servet-i Fünûn dönemi Türk romanı için büyük bir sıçrama olur. Özelde Halit Ziya'nın genelde de Servet-i Fünûn romanında görülen başarı ele aldıkları konulardan değil, roman tekniğinde yaptıklarından ileri gelir. Çünkü Servet-i Fünûn romancıları, “(...) teknik bakımdan, Tanzimat romanının hatâlarından tamamıyla kurtulmuşlar ve modern bir tekniğe sahip olabilmişlerdir. Vakaların kuruluşu, işlenişi ve konuşmalar çok normaldir.” (Akyüz, 1995: 112-113). Servet-i Fünûn romancılarının az roman yazmaları da niceliğe değil, niteliğe önem verdiklerinin bir başka göstergesidir. Halit Ziya'nın Servet-i Fünûn yıllarında yazdığı romanlarında aşk merkezde olmak üzere karamsarlık, kaçış, kötümserlik, aldatma, sevgi, eğitim ve sanat gibi temalar işlenir.

Nemide, Halit Ziya Uşaklıgil'in ${ }^{1}$ Sefile'den sonra yazdığı ikinci romanıdır. Hizmet gazetesinde 18851886 'da tefrikası yapılan Nemide, 1889 'de kitap olarak yayımlanır. ${ }^{2}$ Nemide'nin konusu Halit Ziya'nın birinci dönem romanlarında görülen üçlü aşk hikâyesine dayanır. Yapıtın merkezinde Nemide, Nail ve Nahit arasında geçen aşk yer alır. Osmanlı devletinin kapalı toplum anlayışı nedeniyle Halit Ziya aşkı birbirlerini görme şansı olan yakın akrabalar arasında kurgulamıştır. Yapıtın içeriği daha önce yazılan romanlarla benzerlik gösterir; ama Nemide'nin konusu “(...) başka bir kuşağın, daha serinkanlı tümceleriyle, daha büyük bir ustalıkla örtülmüştür.” (Finn, 1984: 128). Nemide'de geçen kıskançlık da Intibah'ta geçen Mahpeyker'in yaptığı gibi çılgınlık noktasına çıkmaz. Nemide teknik bakımdan da kendisinden önce yazılan Sergüzeşt, İntibah gibi romanlara göre daha tutarlıdır. Nemide'nin Türk romanı için önemi “(...) imge kullanımının bilgi sunma, söylev verme durağanlığından çıkıp simgesel ve devingen bir raya oturtulmasındadır." (Finn, 1984: 129). İmgeye bakıştaki bu değişim aynı zamanda romanın ders vermek için yazılmaktan uzaklaştığını da göstermektedir.

Nemide'nin yazıldığı sıralarda Türk edebiyatında "Hakikiyûn - Hayâliyûn" tartışması söz konusudur. ${ }^{3}$ Türk romanı romantizmden realizme geçiş sancıları yaşamaktadır. Halit Ziya bu tartışmanın dışında kalamaz. Hizmet gazetesinde romanın tanımı, tarihsel gelişimi, Türkiye'de roman, realizm ve romantizm akımlarını da açıklayan dizi halinde yazılar kaleme alır. Bu yazılar daha sonra Hikâye başlı̆̆ 1 altında kitaplaşır. ${ }^{4}$ Halit Ziya'nın Hizmet gazetesinde akımlar üzerine düşüncelerini açıkladığı sıralarda aynı gazetede tefrikası yapılan Nemide coşumculuk akımının etkisindedir. ${ }^{5}$ Oysa Nemide'den önce yazılan,

\footnotetext{
1 Halit Ziya'nın romanları: Sefile (Hizmet'te tefrika ediliği yıllar 1886-1887), Nemide (1889), Bir Ölünün Defteri (1893), Ferdi ve Şürekâsı (1895), Mai ve Siyah (1898), Aşk-ı Memnû (1901), Kırık Hayatlar (1924), Nesl-i Âhir (1990). ${ }_{2}^{2}$ Nemide'nin gerek tefrika yılları gerekse ilk baskısını yaptığı yıllar üzerinde farklı tarihler verilmektedir: Cevdet Kudret Türk Edebiyatında Hikâye ve Roman-I başlıklı çalışmasında tefrika tarihlerinin 1887-1888 olduğunu ve birinci baskının da 1892 olduğunu belirtirken Robert P. Finn ise tefrika yıllarını 1885-1886'yı gösterirken yapıtın ilk baskııının yılını da 1889 olarak göstermektedir. Bu çalışmada Nemide'nin 1984'te Inkılap ve Aka Kitabevi tarafından yapılan baskısından yararlanılmıştır.

${ }^{3}$ Tanzimat sonrasında görülen roman, tiyatro, makale gibi edebiyat türlerinin yanında Batı edebiyatlarında görülen sanat tartışmaları da Türk edebiyatında ortaya çıkar. Bu tartışmalardan biri olan "Hayaliyûn-Hakikıyûn”, Beşir Fuat, Ahmet Mithat Efendi, Muallim Naci, Nabizâde Nâzım Menemenlizâde Fazlı Necip ve Mehmet Tahir gibi Tanzimat dönemi ikinci kuşak edebiyatçıları arasında yaşanır. Romantizm - realizm tartışması olarak da bilinen bu çekişme, Türkiye'de bu akımların daha iyi anlaşılmalarını sağlamıştır.

${ }^{4}$ Halit Ziya Uşaklıgil, Hikâye, İstanbul: Vatan Kütüphanesi, 1891.

${ }^{5}$ Hizmet gazetesi Halit Ziya için sanatın başlangıcı olur: "Sefile, Nemide, Bir Ölünün Defteri, Ferdi ve Şürekâsı adı romanları ile Bir Muhtıranın Son Yaprakları, Bir Izdivacın Tarih-i Muâş̧akası adındaki hikâyeleri, mensur şiirleri ve birçok fennî yazıları bu gazetede yayınlanır." (Kenan Akyüz, Modern Türk Edebiyatının Ana Çizgileri, Istanbul: Inkılap Kitabevi, 1995, s. 113-14).
} 
şeriata aykırı bulunduğu için kitaplaşması yıllar sonra gerçekleşecek olan Sefile romanında ise realizm akımı baskındır. Bu durum şunu göstermektedir: Henüz yirmili yaşlarına ulaşmamış olan Halit Ziya, arayışına devam etmektedir. 1867 'de doğan Uşaklıgil, Nemide'yi yazmaya başladığında on sekiz yaşındadır. Kırk $Y_{l} l$ adlı yapitında Nemide'nin bir hayâl ürünü roman olduğunu belirtir:

"Her genç gibi bende de bir hayal, emellerimin, heyecanlarımın arasında irtisama [şekillenmeye] başlayarak hassasiyetimin daimi bir zairi [ziyaretçisi] bir genç kız hayali vardı ki, (...) ve hayalimin menşuru [prizması] arasından onu, yarı karanlı bir aynaya uzaktan inikas etmiş bir sima gibi seyyal [akicl] ve mütehavvil [değişken] görürdüm. (...) o sadece mütebellir [belirgin] bir hülya, bir genç kız şeklini almış bir mefkure [ideal] idi; (...) dokunulursa solacak, yakından bir nefes dokunursa ölüverecek kadar rakikti [hassastt]. İște 'Nemide' bu hayalden doğdu,(...)” (Uşaklıgil, 2014: 323-324).

Bu alıntı da Nemide'nin gerçeğin dışında, yazarın hayâl dünyasının bir ürünü olduğunu kanıtlar. Araștırmacı Robert P. Finn de Nedime'nin romantizm akımının etkisinde yazılan bir sanat yapıtı olduğunu, "Konunun basmakalıplığını giderecek, dengeleyici bir psikolojik gelişim olmadığından, son derece ağdalı bir romantizm egemendir romana"(Finn, 1984: 131) diyerek açılar. Kenan Akyüz de Servet-i Fünûn romanlarını değerlendirirken romantizm akımından kurtulmanın zorluğuna gönderme yapar. "Servet-i Fünûn romancılarının önceleri daha çok romantik örneklerle karşılaştıkları anlaşılır. Bunun içindir ki onların ilk denemelerinde realizmin izlerine rastlanmamasını tabî̂ görmek gerekir." (Akyüz, 1995: 111). Akyüz sözlerinin devamında Türk edebiyatındaki gerçekçi eserlerin azlığına da dikkat çeker. ${ }^{6}$ Halit Ziya'nın Nemide'den sonra gelecek olan romanlarında realizm akımı hep baskın durumda olacaktır. Kendisi de Hikâye adlı kitabında realistleri romantiklere tercih ettiğini belirtir; ${ }^{7}$ fakat bu düşüncelerini açıkladığı zaman Nemide'nin tefrikası çıkmış durumdadır. Halit Ziya romantik akımı tümüyle terk etmez. Mai ve Siyah 'ın başat kişsisi olan Ahmet Cemil gibi kahramanları üzerinden bir damar olarak bu akımı da yaşatmayı sürdürür.

\section{Coşumculuğun Gölgesinde Bir Roman Olarak Nemide}

İlk izleri 1750'lerde önce İngiltere'de sonra da Almanya'da görülen romantizm, ${ }^{8} 1830$ 'larda da Fransa' da yaygınlaşınca egemen akım durumuna gelir. Klasiklerin devri tamamlanır. Halit Ziya'nın ikinci romanı olan Nemide, yukarıda da vurgulandığı gibi romantik akımın gölgesinde yazılmış bir yapıttır. Yapııın konusunu aşk, eğitim, Şevket Bey'in Kanlıca'daki gül bahçesi, hastalık ve ölüm oluşturmaktadır. Zaten romantizm akımının konusu da “(...)genellikle, aşk, doğa ve ölümdür.”(Karaalioğlu, 1980: 59). Yapıtın son sayfasında Nemide'nin ve Naime'nin hayali gözükür. Şevket Bey, bir hayal olan Naime'yle konuşur: "O zaman yaşlı insan parmağını dudaklarının üzerine koyarak: 'Sus!' dedi. Köşede, hayal olunan bir şeyi göstererek dedi ki: 'Nemide uyuyor.' Yine bu sırada bir gece, ışık içinde bir odanın sediri üzerinde genç bir gelin vardı, dizlerinin dibinde güzel bir delikanlı' sevgiyle dolu gözleriyle karısına bakıyordu." (s. 149). Hayal ve olağanüstü romantik akımın özellikleri arasındadır: "Romantizmde hayâl ve fanteziye geniş yer verilmiş (...)" (Karaalioğlu, 1980: 59)'tir. Eseri oluşturan verem, sarı renk, tezat unsurlar, kaçış, ikilemler, ay ışı̆̆ı ve zayıf karakterler yapıtın romantizm etkisinde yazıldığını gösteren diğer unsurlardır. Karaalioğlu romantik akımın özelliklerini sayarken "Romantizm, ağlayan bir yıldızdır; romantizm, ürperen gecedir. Romantizm; beklenmeyen bir parıltt, hasta bir sarhoşluktur"(a. g. e., s. 61) demektedir. Bu açıklamada geçen özelliklerin tamamı Nemide'de görülmektedir. Nemide barındırdığı Romantik unsurların yoğunluğuna göre bu çalışmada irdelenmiştir.

\section{1. Sarı Renk Nemide'de Sadece Sayfaların Rengi Olarak Kalmaz.}

Halit Ziya'nın Nemide romanına "sarı" bir renk olarak damgasını vurmuş durumdadır. Kitapta sarı, sararmak, sapsarı olmak üzere on sekiz kez geçmektedir. ${ }^{9}$ Zaten Halit Ziya'nın bu romanda etkisi altında

\footnotetext{
${ }^{6}$ Akyüz sözlerine şunları da ekler: "1880'den sonra Fransız realizminin Türk romanına sızışı çok ağır bir tempo ile olduğu, bu eğilime yer vermiş olan (...) üç romandan yalnız Sergüzeşt 'in 1888 de basıldığı ve diğer ikisinin ise ancak 1896'dan sonra (Zehra: 1896, Araba Sevdası: 1898) yayınlandıkları dikkate alınırsa(...)" (Kenan Akyüz, Modern Türk Edebiyatının Ana Çizgileri, istanbul: Inkılap Yayınları, 1995, 111).

${ }^{7}$ Bkz. Bilge Ercilasun, Servet-i Fünûn'da Edebî Tenkit. Ankara, Meb Yayınları, 1984, s. 181.

${ }^{8}$ Romantizm akımının birden çok tanımı söz konusudur. Şu şekilde yapılabilir: "Romantizm; on sekizinci yüzyılın sonunda başlayan, klasik edebiyatın yerine geçen, duygu ve hayale fazla yer veren edebiyat çı̆ıııdır. Romantizmin babası Roussseau'dur. Kant, Fichte, Schelling romantizmin felsefí hazırlayıcılardır." (Seyit Kemal Karaalioğlu, Edebiyat Akımları, istanbul, Inkılap ve Aka Kitabevleri, 1980.)

${ }_{9}^{9}$ Bkz., Sarı rengin geçtiği sayfalar: 16, 17, 24, 36, 42, 73, 83, 105, 110, 116, 118, 125, 129, 134,136, 138, 146 ve 147.
}

195 | P a g e

www.iiste.org 
kaldığı romantizm akımında da hâkim renk sarıdır. ${ }^{10}$ Romanın henüz başlarında sarı renge gönderme yapılır. Yazar on altı yaşında dediği Nemide'nin fiziksel özelliklerini sayarken "Vücudunun çelimsizliği, cildinin saydamlığı Nemide'yi nemli bir yerde açmış sarı bir çiçeğe; yahut bir bahar bulutuna benzetirdi”" (s. 7) vurgusunu yaparak hem kahramanın güçsüz bir bedene sahip olduğunu açıklar hem de sarı renge değinir.

Sarı, renk olarak romantizm akımında hastalığın göstergesidir. Romanda da başat kişilerden Nemide verem olarak okurun karşısına çıkarılmıştır. Nemide'nin yüzündeki sarılık zaman zaman sapsarıya döner: "Bir genç kız görülür ki, tutup terzisinin ufak bir eksiğine öfkelenmiştir, dudakları titriyor, gözleri kanlanmış, benzi sapsarı kesilmiş, vücudu kuvvetli titremelerle kemikleri çözülecekmiş gibi sarsılıyor,(...)" (s. 36). Hastalık nöbetleri geldikçe bu alıntıda olduğu gibi yüzü değişir, sarılaşır. Nemide'nin yüzündeki sarılık psikolojisinin de bozulmasına neden olur. Bir gün aynaya bakar: “(...) dirseğini mermerin üzerine dayayarak bir zaman hazin hazin kendisini seyretti. Yüzünde korkunç bir sarılık vardı, genç kız görünüşünden ürktü.” (s. 73). Bu ürküntü ağlamasıyla sonuçlanır: “(...) büyük bir gürültü ile kapısını kapattı, kendisini sedirin üzerine attı, hüngür hüngür ağlamaya başladı.” (s. 73). Nemide'deki sarı renk, roman boyunca hastalık dışı unsurlarla da varlığını sürdürür.

Romanda Nemide sarı saçlı bir kız olarak anlatılır. Nail'le Nemide arasında geçen bir konuşmada sarı saçlarına değinilir: "Nemide, sanki genç amcaoğlundan bir adım uzakta bulunursa onun varlığının tadından mahrum kalacakmış gibi Nail' in yanına çıktı, vücudunu yarı eğdi, sarı saçları amcaoğlunun omuzuna döküldü.” (s. 28). Nemide’nin zayıf kolları sarı saçlarını yapmakta yetersiz kalır: "Özenle saçlarını taramaya başladı, hatta bir tarafını da gevşek bir şekilde örmeyi başardı, lâkin öteki tarafını örmeye zayıf kollarındaki kuvvet yetmedi. İnce parmaklarını saçlarının sarı telleri arasına sokarak üçe ayird1." (s. 129).

Nemide'de sarı rengin gözükmesine diğer kahramanların eylemleri, sözleri de neden olur. Nemide'nin elini nişanlısı Nail tutunca sararır: "Nemide gözlerini kaldırdı, sarı benzini hafif bir kırmızılık kaplamıştı." (s. 91). Nail'le Nahit arasındaki gizli aşk, Nemide'nin keyfini kaçırır, sararmasına neden olur: "Nahit' in elinde bir hiddet eseri, çehresinde bir isyan nişanı vardı. Elini Nail' in elinden çekmişti. O zaman Nemide anladı, sapsarı kesildi." (s. 110). Nemide'nin 1srarıyla başlayan sandal gezisinde de sarı renk ortaya çıkar. Akıntılara sürüklenen sandalda Nahit düşer. Bu duruma Nail tepki gösterir. Bu tablo karşısında "Nemide sapsarı kesilmiş, dişleri kilitlenmişti." (s. 146). Nemide' de görülen sarı rengin yoğunluğu okurun Nemide’ye yönelmesini de sağlar.

Yapıtta Nemide'nin dışında Şevket Bey, Nahit ve Nail'de de sarı renk görülür. Her ne kadar Nemide'de olduğu gibi bunlardaki sararma vurgulu olmasa da yazarın bu tutumu, roman içerisinde sarı rengin yaygınlaşmasına ve hâkimiyetine neden olur. Nemide'nin ayrılacağını söylemesi üzerine nişanlısı sararır: "Nail'in yüzüne baktı, delikanlı sapsarıydı." (s. 136). Nemide'nin nişan yüzüğünü Nahit'e takması sırasında sarı renk ortaya çıkar: "Nahit sapsarı kesilmiş ne yapacağını bilmeyerek şaşıp kalmıştı.” (s. 138). Başka sayfalar da Nahit'in zaman zaman sarı renge büründüğü belirtilir. ${ }^{11}$

Yapıtta sarı renk farklı şekillerde de ortaya çıkar. Nail, Nemide ve Nahit birlikte Kâğıthane’ye giderken gördükleri çocukların elbiseleri sarı renklidir: "Birdenbire bir kahkaha kopardı, şemsiyesine dayanarak geçmekte olan sarı elbiseli bir kızı göstererek (...) Demin beğendiğiniz kızın saçları gibi...” (s. 45). Şevket Bey'in yalnızlığına son vermek için evlendiği Naime’yi kontrole gelen doktorda da sarı renk görülür. "Kapıyı açtığı zaman ocağın yanında doktor benzi sapsarı kesilmiş olduğu halde duruyordu." (s. 19). Nemide okula gidemeyeceğini duyunca ağlar. Kızının üzüntüsü karşısında Şevket Bey “(...) duygu coşkunluğu karşısında sapsarı”(s. 33) kesilir. Halit Ziya sarı rengi pekiştirmek için Nemide’nin Kanlıca'daki yalıda bulunan "Odanın pencereleri beyaz tülden uzun perdelerle örtülmüştü, perdelerin kanatları pembe bağlarla toplanmış olduğu halde pencerelerin iki tarafindaki sarı askılara asılmış idi”" (s. 54) diyerek sarı rengin yoğunluğunu ortaya koyar.

\section{2. A ğlamak ya da gözyaşı}

Nemide'de mensur şiiri çağrıştıran ve romantik yapıtlarda önemli yer tutan gözyaşı sıkça geçer. Sarı renkten sonra romanın başından sonuna kadar gözyaşı hâkimdir. Cevdet Perin coşumculukta vazgeçilmez unsurların başında gelen gözyaşı ve ağlamak için şu açıklamayı yapar: "Romantizm ağlayan bir yıldızdır, romantizm inleyen rüzgârdır, romantizm ürperen gecedir... Romantizm beklenmeyen bir parıltı, hasta bir sermestîdir." (Perin, 1942: 10). Romanda gözyaşı daha çok Nemide'de ortaya çıkar.

\footnotetext{
${ }^{10}$ Romantizm akımında egemen rengin sarı olduğunu belirten Suut Kemal "(...) baharın yeşilliğinden çok sonbaharın sararmış yapraklarının, tan kızıllığının yaşama sevinci veren türkülerinden çok akşamın hüzünlü ezgilerini duyarız." (Yetkin, 1967, s.31) diyerek romantik akımdaki sarı renge vurgu yapar.

${ }^{11}$ Bkz. s. 77.
} 
Nemide gerek hastalığı gerekse yaşadığı şansız aşk hayati nedeniyle sıkça ağlar. Onun dışında annesi Naime'de, Şevket Bey'de ve teyzesinin yanında yaşayan Nahit'te de görülür.

Nemide birlikte büyüdükleri Nail' in tıbbiyeye gideceğini duyunca kendisi de o okula gitmek ister; fakat babası kızların tıbbiyede okumalarının yasak olduğunu söyleyince Nemide önce tepki gösterir, sonra ağlar: "Bu sözlerin arkasından Nemide'nin gözlerinden bir gözyaşı yağmuru boşandı, bu yaşların utancından saklamak istiyormuş gibi başını babasının göğsüne dayayarak hüngür hüngür ağlamaya başladı." (s. 32-33). Kızının üzülmesi karşısında sapsarı kesilen baba " Niçin ağlıyorsun? Sen okumak istiyorsan ben seni okutayım..."(s. 33) diyerek bir çare bulmanın peşine düşer. Halit Ziya bu sahneyi kurgulayarak kızları//kadınların eğitimine ve erkeklerle eşit olmalarının gerekliliğine de gönderme yapar. Zaten eşitlik de coşumculuk okulunun bir özelliğidir. ${ }^{12}$

Nemide Nail'e âşıktır. Babasıyla yapmış olduğu bir konuşmada Nail'e olan aşkını doğrudan söylemek yerine ağlayarak söylemeyi tercih eder:

“-Nemide, niçin ağliyorsun?

Nemide sertçe elini çekerek ayağa kalktı, öfkeli, bir sesle

Ondan nefret ediyorum, dedi.

Heyhat! Zavallı kız!...” (s. 72).

Verem olan Nemide, hastalığın vermiş olduğu acıdan, üzüntüden ötürü de ağlar: "Korkunç bir sinir kasıntısı bütün vücudunu kıvırıyor, bu incecik vücudu bir mengene arasında eziyordu. Genç kız elinde olmadan, içten gelen bir zorlama ile ağlıyordu." (s. 73). Hastalık yazarın ağlama unsurunu yaratırken işini de kolaylaştırır. Çünkü hastalık üzülmek, ağlamak için iyi bir nedendir. Nemide bazen babasına gerçek ağlama nedenini söylemez. Nail'e kızdığı bir gün babasına güneş altında fazla kaldığını söyler; fakat kendini odasına atıktan sonra. "Bir dakika sonra genç kız yatağının içinde rahat ağlıyordu." (s. 119). Nahit ve Nail gece gizli buluştuklarında birbirlerine gül verirler. Bu tablo karşısında Nemide'ye ağlamak düşer: "Ama gözlerinin önünde bir el tuttuğu gülü başka bir ele uzatıyor, garip bir bakış karanlık arasından başka bir bakışı araştırıyordu. Bu hayal gözünde canlanıyor, genç kız yürekten ağlıyordu.” (s. 108). Gizlice buluștuklarında Nail, Nahit'e eğer aşkımızdan Nemide'nin haberi olursa bu durumun onu yok edeceğini belirtir. Bu konuşmaya tanık olan Nemide ağlamak ister: “( ...) kendisini pek bahtsız buldu, ağlamak istedi.” (s. 110). Babasına Nail'i sevmediğini söyleyip yüzüğü parmağından çıkarır. Bu hareketten sonra baba-kız birlikte gözyaşı dökerler: “(...) genç kızın başı babasının omuzuna düştü. Nemide ruhu ağlıyormuş gibi, yaslı bir sessizlik ile gözyaşlarını salıverdi.”(s. 122). Peșinden babanın gözyaşları "Nemide'nin sarı saçlarını 1slatıyordu" (s. 122) denilerek birlikte ağladıkları gösterilir. Nemide Nail'den tamamen ayrılırken de ağlar. ${ }^{13}$ Nemide'nin ağlaması doğumundan ölümüne kadar sık skk devam etmiş̧ir.

Eserde Nemide'den sonra Şevket Bey ağlayan kahramanlardan biri olur. Onun ağlaması önce çok sevdiği eşinin hastalı̆̆ nedeniyle olur: "Doktorlar gittikleri zaman Şevket Bey kalbinde bir hançer saplantısı duydu. Ağlamak korkusuyla karısının yanına girmeye cesaret edemedi;"' (s. 15). Şevket Bey’i eşinden sonra ağlatan ikinci kişi ise kızı olur. Naime öldükten sonra Doktor Osman Bey henüz yedi aylıkken dünyaya gelen Nemide'yi Şevket Bey’e verince, “(...) dizlerinin üzerinde şaşkın şaşkın bakan kızını seyrederek uzun uzun ağladı. Bu gözyaşları kalbini dolduran bütün yas duygusunu boşaltıyordu.” (s. 24). Şevket Bey'in eşi de ağlar. Hastalığı sonrasında dudakları kilitlenen Naime, eşine karşıllk veremeyince ağlar: "Bu iki katreyi bol bir gözyaşı izledi, genç kadın birinci defa olarak ağllyordu.” (s. 18). Böylece aileyi oluşturan bütün bireyler ağlamış olur.

Romanda ağlayan kahramanlar arasında yer alan Nahit, babasından ayrılıp teyzesinin evine gelir. Orada uzunca ağlar: "Bir gün babasından aldığı izin üzerine teyzesinin evine geldi. Bu küçük kız o zamana kadar sakladığı umutsuz duygularını daha ziyade saklayamadı, teyzesinin kolları arasına atılarak hüngür hüngür, uzun uzun ağladı.” (s. 47). Bu olaydan sonra Nahit babasının evine dönmez. Nahit teyzesinin evinde yalnızlık duygusunu fazla çekmez: bir süre daha ağlamaya devam eder: “(...) kalp tarafindan eziyette değildi, çünkü kendisini burada seven bir kalbin varlığına inanıyor, kafasında annesinin hatırasını yaşatacak bir yüz görmekle avunuyordu.” (s. 48). Nahit Kanlıca'daki yalıya gider. Orada kendisine verilen odada yaşadığı hayata, içine girdiği çıkılmaz aşk da isyan ederek ağlar: "Bahtsızlığı kararlaşmış, çarp ildiği felâketin altından kalkamayacağını iyice anlamış bir zavallı gibi açık açık ağlıyordu." (s. 83). Nail ve Nahit gece gizlice buluşurlar. Bu buluşma sırasında Nail'i elinden

\footnotetext{
${ }^{12}$ Ayrıca romantizm akımını doğuran 1789 Fransız Devriminden hemen sonra "Kadın ve Kadın Yurttaş Hakları Bildirgesi" yayınlanır. Batı'daki gelişmeleri bilen 19. yüzyıl Türk aydını da kadınla erkeğin her bakımdan eşitliğini savunmuşlardır. Bu durum Servet-i Fünun roman ve öyküsünde daha net görülür.

${ }^{13}$ Bkz., s. 134, 139.
} 
kaçıracağını düşünen Nahit, çektiği acıdan ötürü ölmek üzere olduğunu belirtir: "Nail sustu. Genç kız can yakan bir acıyı yatıştırmak istiyormuş gibi ellerini göğsüne basarak ağlamaklı bir sesle: Ölüyorum, dedi." (s. 99). Nahit'in bu sözleri üzerine Nail sizin bu duruma gelmenizde etkim olabileceğini düşünemiyordum der.

\section{3. Zayıflık, Güçsüzlük}

Nemide romanında kahramanlar hem ruhsal hem de fiziksel olarak zayıftırlar. Bu kişilerin başında da Şevket Bey’in eşi Naime ve kızı Nemide gelir. Onlardan sonra annesi omayan Nahit gelir. Halit Ziya yapıtta kadınların genel olarak yaşam karşısında güçsüz olduklarını vurgular. Bunu da roman kahramanlarından Nahit üzerinden verir. Nahit "Kadınlar hayatlarını idare edebilmek için o kadar zayıftırlar ki evlenme onlar için bir ikinci beşik olur" (s. 79) dedikten sonra kadınların korucuları olarak da "Bir babası, bir anası var"(s. 80) vurgusunu yapar.

İki yıllık kaçıştan sonra İstanbul'a dönen Şevket Bey, çocuğunu tekrar yanına alır; fakat Nemide o kadar zayıftır ki "Çocuk bu sırada iki yaşında bulunuyordu; ama zayıflığı, vücudunun sürekli bir bakıma sıkıcı ihtiyacı, zavallı çocuğu daha altı aylık gibi gösteriyordu.” (s. 24). Nemide özel bakımla ve doktor kontrolünde büyür. Nemide'nin zayıflığı okula gitmek isteyip de gidemediğinde de ortaya çıkar: "Hıçkırıklar kızcağızın zayıf göğsünü sarsıyordu.”(s.33). Çocuğunu çok seven Şevket Bey, kızı Nemide'nin güçsüzlüğü nedeniyle hedeflerine ulaşamadığı zamanlarda ona destek olur. Nail'e yetişmek için gösterdiği aşırı gayretin, çocuğun zayıf yapısını yormaması için dersi erteler: "Nemide o derece kuvvetli bir heves gösteriyordu ki cuma günlerinde derslerin yapılmamasına Şevket Bey büyük bir direnme ile başarabilmişti.” (s. 34). Nemide'nin güçsüzlüğü saçlarını tararken de kendini gösterir: "Özenle saçlarını taramaya başladı, hatta bir tarafını da gevşek bir şekilde örmeyi başardı, lâkin öteki tarafını örmeye zayıf kollarındaki kuvvet yetmedi. (...) parmakları birdenbire durdu, genç kızın kolları dokunaklı bir gülümsemeyle düştü.” (s. 129). Nemide ölürken babasına sarılmak ister fakat güçsüz kolları kendini son nefesinde de gösterir. Roman boyunca Nemide'nin tekrar eden zayıflığı romantizm akımın yansımalarından biridir.

Yapıtta Şevket Bey’in eşi Naime de fiziksel olarak zayıf bünyelidir. Rahatsız olduğu bir gün Şevket Bey'in konağına gelen Doktor Osman Bey, ona eşinin dinlenmeye, bakıma gereksinim duyduğunu söyler: "Zevcenizi istirahate çok muhtaç görüyorum. Bünye yapılışını pek zayıf buldum.” (s. 15). Doktor sonra “(...) böyle zayıf bünyeli kadınlar için pek tehlikeli olan çocuk doğurmaktan sakınılırsa zevceniz sağlıkla hayatını geçirir” (s. 15) diyerek yaşamına devam edebileceğini söyler. Doktor sözlerine hamile kalmanın risk taşıyacağını da ekler; fakat doktorun uyarılardan önce Naime hamile kalmış durumdadır. Şevket Bey’in eşinin zayıflığı ölümü sırasında gözükür: "Naime, koltuk sandalyesinin içine gömülmüş, kolları güçsüzlükle aşağıya doğru sarkmış; bakışsız boş gözleri bilinmez bir noktada kaybolmuş," (s. 16). Bunların dışında romanda Nahit'in de güçsüzlüğünün vurgulandığı yerler geçer. ${ }^{14}$

Eserde kahramanların zayıflıklarının dışında çekingen oldukları üzerinde de durulur. Nemide'nin üzüldüğü zamanlarda Şevket Bey kızına çekinerek bakar: "Şevket Bey acı, çekingen bir gözle kızına bakmaktaydı. Zihninden şimşek gibi bir fikir geçmiş, gözlerinin önünden bir bulut kalkmıştı.” (s. 72). Şevket Bey'deki bu tutum Nail'de de görülür: "Nail çekingen bir davranışla Nemide'nin elini tuttu." (s. 91). Nail, Nemide'ye kendini sevip sevmediğini sorarken de çekinir: "Nemide'nin kalbi mutluluk duygularının hücumuna dayanamıyormuş gibi şiddetle çarpıyordu. Nail, çekingen bir davranışla daha çok yaklaştı; istekle titreyen bir seda ile: — Nemide! Beni seviyorsun, değil mi, dedi." (s. 92). Nahit Kanlıca'daki yalıda kalırken Nail'le gizlice buluşur. Bu buluşmalara giderken de çekinir: "Gölge çekingen bir yürüyüş ile ilerledi. Biraz sonra bu gölge belli oldu; Nail, Nahit olduğunu anladı.”(s. 99). Şevket Bey, Nemide'nin kızgın olduğu zamanlar ona bir şey söylemekten çekinir: "Nail, Nahit'i seviyor. Niçin onu bana tutsak olmaya zorluyorsunuz? Şevket Bey çekingen bir sesle: 'Yanıliyorsun!' dedi.” (s. 139). Zayıflıkla birlikte ele alındığında çekinme teması esere bir bütünlük de verir.

\section{4. Verem}

Yapıtta romantizm akımında sıkça görülen verem hastalığı önemli bir yer tutar. Halit Ziya, Nemide’yi veremin etkisi altında yazmıştır. ${ }^{15}$ Eserin başat kişilerinin önünde gelen Nemide, veremdir. Onun verem olduğunu Doktor Osman Bey, “(...) dudaklarının arasından kendi kendisine fikir anlatıyormuş gibi 'Verem!... sinir!...’”(s. 37) sözleriyle açıklar. Kızının verem olduğunu öğrenen Şevket Bey büyük bir şok yaşar: "Gözünde bu kelime çok korkunç bir ejder gibiydi, sandı ki ateş saçan bulutlar içinde yuvarlanan, ateşten yaratılmış bir cehennem ejderi Nemide'yi alarak kendisinin gidemeyeceği bir belâ fezasına götürüyor.” (s. 37). Şevket Bey’in veremin etkisinden kurtulması kolay olmaz: “(...) kulaklarında 'Verem!'

${ }^{14}$ Bkz., 126.

15 Verem, Halit Ziya'nın Ferdi ve Şürekâsı, Mai ve Siyah ve Aşk-ı Memnu'da da romanın kurmaca dünyasına taşınır. 
sözü yaslı bir çınlama ile tekrarlanıp duruyordu.” (s. 38). Daha sonra veremin Nemide'nin yaşamında oynayacağı olumsuz role değinilir: "Ufak bir ihtiyatsızlık onu o uçurumun korkunç derinliklerine atmaya yeter." (s. 38). Fakat Doktor Osman Bey, Şevket Bey'e umut vermekten de geri durmaz: "Ama biz Nemide'yi o uçurumun kuvvetli çekişine karşı hekimliğin en kuvvetli bağlarıyla ${ }^{16}$ bağladık. Emin ol, Nemide'yi kaybetmeyeceksin" (s. 38) der. Romanda Nemide'nin nişanlısı olarak okura sunulan Nail'i de Nemide'deki verem düşündürür: “(...)bu korkunç hastalığın kızcağızı tâ pençesinin içine alıp ezeceğini sanmamıştı. (...) Nail bu hastalığın orada, genç kızın parmağının altında zehirli bir bez gibi bu zavallı vücuda zehirleyici salgılarını salıverdiğini düşünerek çok korktu.” (s. 133). Nemide ile Nail arasında geçen bir konuşmada Nemide, Nail'e yazgının kendisine veremli bir kızı çıkardığını belirtir: "Garip bir talih sizin hayat yolunuzun önüne hasta, verem bir kız koydu." (s. 135). Nemide'nin belirttiğine göre, Nail'in aklı uysa da duyguları onu kabullenememiștir: "Siz pek yüksekten gelen bu sesi dinlediniz, fakat sizin uyduğunuz bu vazifeye duygularınız uymadı." (s. 136). Bu ifadeleriyle Nemide ölüme giderken veremin dışında ikinci suçlu olarak da Nail'i gösterir. Aynanın karşısında olduğu bir gün Nemide hizmetçisine mutsuzluğunu anlatır: "Bir aralık Nergis'i çağırdı: —Bak! Nergis yaklaştı. Nemide gözlerini aynadan ayırmayarak parmağını yanağına bastı, kaldırdığı zaman yerinde donuk bir izden başka bir şey görülmedi, 'Hiç kan yok!' dedi.” (s. 129). Görüldüğü gibi verem Nemide'yi derinden sarsmış ve üzmüştür.

\section{5. Kaçış}

Egzotik yerler olarak romantizmde görülen kaçış, bireyin içinde bulunduğu yaşamdan sıkılması ya da baş edemeyeceği olaylarla, durumlarla karşılaşınca uzaklara gitmesi olarak bilinir. Yani, "baskı'dan ve zorluk'tan kaçıştır." ${ }^{\prime 7}$ Nemide'de birden çok kaçış görülür. Kahramanlar zor durumda kalınca arayış içerisine girerler. Romantizm akımında kahraman kaçarak “(...) dış dünyanın karışıklığı karşısında iç dünyaya yönelir;(...)” (Karaalioğlu, 1980: 64). Nemide'ye baktığımızda bulunduğu ortamdan kaçan kahramanlar yalnız kaldıklarında iç dünyalarıyla yüz yüze gelirler.

Romanda karşımıza çıkan ilk kaçış Şevket Bey’de görülür. Çok sevdiği eşini kaybeden Şevket Bey, hastalığını yendikten sonra “(...) sâdık hizmetkârı Ömer Ağa ile uzun bir yolculuk yapmak için Suriye taraflarına gidiyordu." (s. 21). Şevket Bey'in bu kaçışı iki yıl sürecektir; fakat okuyucu onun Suriye'de ne yaptığını bilmez. Yazarın Suriye'deki Şevket Bey'i anlatmaması romantik akımın bir özelliğidir. Bu durumu Bilge Ercilasun, Halit Ziya'nın Hikâye adlı kitabından şu şekilde aktarır: "Hayaliyûn, şahısları bize bütün zâtî hususlarıyla, çılak olarak göstermez. Onların yalnız dı̧ ahvalini arz eder, hayatını, ruhî ahvalini meskut geçer." (Ercilasun, 1994: 181). Şevket Bey'in Batı'ya değil de Doğu'ya gitmesi de Romantizm akımının egzotik âlemleri daha çok Doğu'da aramasıyla yakından ilgilidir. ${ }^{18}$ Şevket Bey için gül bahçesi ve kütüphanesi de zaman zaman bir kaçış yerine dönüşür.

Şevket Bey'den sonra kızı Nemide'de de kaçış duygusu yer alır. Nemide, Nahit'i kendisine rakip olarak gördükten sonra canı sıkılır. Babasının Kanlıca'daki yalıya gideceklerini söylemesi üzerine Nemide çok mutlu olur. Daha da uzaklara gitmek ister:

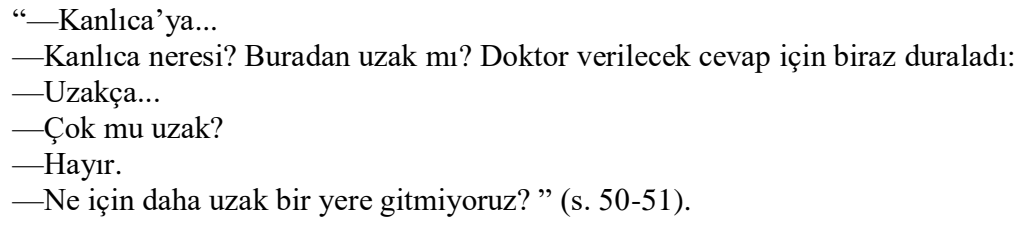

Nemide'nin daha uzaklara gitme isteği Şevket Bey'le Osman Bey'i şaşırtır. Sorarlar neden daha uzaklara gitmek istediğini "Nemide eliyle uzak bir yeri gösteriyormuş gibi bir işaret ederek: 'Uzak... uzak olmak için...”' (s. 51) der; ama gerçek nedenini açıklamaz. Romanın sonlarına doğru Nail'in Nahit'i sevdiğini öğrenen Nemide, bu kez de birlikte çıktıkları sandal gezisinde uzaklara gitmek ister: "Birdenbire Nail küreğini bıraktı, dedi ki: - Daha ileriye gitmek mümkün değil! Nemide cevap verdi: — Hakkınız var, yoruldunuz. Ama ötesi o kadar güzeldir ki..." (s. 144). Görüldüğü gibi içinde bulunduğu ortamdan sonunda ölüm de olsa gitmek ister. Mutluluğu uzaklarda arar.

Bir kaçış yeri olarak doğa, romantik akımda kişiler için huzurun sembolüdür. Nemide'nin atıyla geziye çıkması, hem kendisinin hem de babasının gül bahçesinde kendilerine gelmeleri insanlarda

\footnotetext{
${ }^{16}$ Alıntılarda özgün metinlere bağlı kalınmıştır.

${ }^{17}$ Bkz., Ahmet Oktay, Zamanı Sorgulamak, ìstanbul, Remzi Kitabevi, 1991, s. 29.

18 "Coğrafi keşiflerin birikimi ile Klasisizmin ideallerin yerini egzotik yakın ve uzak doğu alır." (Ömer Solak, Kuramdan Uygulamaya Edebiyat Çalışmaları, Ankara: Anı Yayıncılık, 2014, s. 73.)
} 
bulamadıklarını doğada bulmalarındandır: “(...) insanlar arasında bulamadıkları rahatlığı ve dinlenişi doğada bulur, hatta toplumuyla kuramadığı iletişimi doğayla kurarak bu iletişimde toplumsal yalnızlığının acısını çıkarır.” (Yücel, 1981: 64). Coşumculuk okulunun temsilcilerinden Chateaubriand'ın, Lamartine'in doğaya gitmeleri doğayı sadece bir sığınak olarak bulmalarından değil, aynı zamanda orada kendilerini de bulmalarından ileri gelir.

Romanda Nemide ve Şevket Bey dışında diğer kahramanlarda da kaçış düşüncesi vardır. Nail'le Kanlıca'daki gül bahçesinde gizlice buluşan Nahit, Nail'e "Fırlayarak ayağa kalktı: — Oh! Kaçalım, kaçalım! dedi." (s. 101). Kuşkusuz Nahit'in bu kaçış isteği Nail'i yitirme kaygısındandır. İleriki yıllarda Mai ve Siyah'ta olduğu gibi, Halit Ziya'nın vazgeçemediği temalardan biri olacaktır kaçış.

\section{6. İkilem/Zitlık}

Halit Ziya'nın bu romanında, romantik akımın dikkat çeken niteliklerinden olan ikilem ve zıtlık da yer alır. Zıtlık, “(...) kişinin iç ve dış dünyasının anlatımı, duygu alemi, melankolik temalar, marazilik(...)"(Karaalioğlu, 1980: 63) olarak romantik yapitlarda kendini gösterir. Roman kahramanları karar vermekte zorlanırlar. Özellikle Nemide, Nahit, Nail ikilem ve tezat davranışlar içerisindedirler.

Nail' in yalıdan ayrılacağı akşam Nemide ikilemde kalır: "Nail'in gideceğinden üzülmüştü. Ama bunun için ağlamak lazım gelip gelmeyeceğini bilemiyordu.” (s. 64). Nahit'in Nail'i sevdiğini anlayan Nemide, Nahit'in ağlaması üzerine "Karşısında ağlayan bu kıza acımak mı, yoksa düşman olmak mı lazım geleceğini bilemiyordu.” (s. 83). Nemide'nin Nail'le yaşadı̆̆ı ilişkinin sonunu bilememesi de ikilemde kalmasına neden olur: "Fakat bu bilmemezlik Nemide'yi, Nail'i son derece bir tutkunlukla sevmekten alıkoymuyordu; tersine bu ne olduğunu anlayamadığı sevgi, genç kızı hasta ediyor, kalbini kemiriyor, öldürüyordu.” (s. 90). Nail, Paris’te üç yıl kalır; fakat iki kez tatile gelir. Bunlardan birinde Nemide’yi ziyarete gider. "Ama Nemide umulduğu gibi teyze oğlunu iyi karşılamıyordu. Kafasını bu kadar kurcalayan, kalbinde bu kadar çok yer tutan bu adam hakkında bir çeşit düşmanlık duyuyordu. Aşkın sevgiden çok düşmanlığa eğilimi vardır.” (s. 67). Görüldüğü gibi Nemide ikilem içindedir.

Nahit, Nail ve Nemide birlikte sohbet ederken Nahit önce gitmek ister. Bu isteğine Nemide "Ne çabuk canınız sıkıldı" (s. 76) diye tepki verir. Nemide'nin bu sözleri üzerine Nahit fikrini değiştirir: "Nahit biraz düşündükten sonra ağır bir zahmete katlanıyormuş gibi fikrini değiştirerek yavaş bir sesle, 'Oturalım!...' dedi.”' (s. 76). Bu örnekte de görüldüğü gibi kahramanlar sürekli farklı kararlar verebilecek durumdadırlar. Nahit Kanlıca'daki yalıda sıkıldığı zaman teyzesinin yanına dönüp dönmemekte karar veremez: “(...) bugünü büyük bir kararsızlık içinde geçirdi. Fikri Kanlıca'da kalmakla, teyzesinin yanına dönmek arasında sallanıyordu. Oraya gidip de ne yapacak? Nail'in yanında bulunacak değil mi?” (s. 87). Nahit'in Nemide'yi öldürmek için odasına kadar girip sonra fikir değiştirerek bahçeye kaçması da bir başka ikilemdir.

Romanda iki kız tarafından sevilen Nail de tereddüt yaşar. Bu iki kızın kafasını meşgul ettiği üzerinde durulur: "Nahit!... Nemide!... Bu iki isim fikrini tırmalıyor(...)" (s. 98). Halit Ziya Hikaye adlı kitabında "Nail hafif, lâkayd, hissiz bir delikanlıdır. Genç kızların ikisini de sevmiyor, fakat ikisine de meyyal (...)" (Aktaran Finn, 1984: 124) diyerek Nail'in hangisini seveceği konusunda kararsız olduğunu belirtir. Yine kızların kararlı hareket etmelerine karşın "Nail gibi silik bir erkeğe ilgi duymaları" (Finn, 1984: 128) da ayrıca zıtlık oluşturmaktadır.

Nemide ve Nahit ayni anda Nail'i sevdikleri için aralarında bir kıskançlık ${ }^{19}$ söz konusudur. Fakat yan yana geldikleri zaman aralarındaki nefreti gizlemeyi yeğlerlerken zıt duyguları birlikte yaşarlar: "Bir zaman iki genç kız birbirine bakıştılar. Bu bakış sevgiden çok derin bir düşmanlığa, çok büyük bir nefrete tercüman olabilirdi.”( s. 55). Benzer tezat durumlar başka sayfalarda geçer. ${ }^{20}$

Yapıtta ölüm ve yeni başlangıç arasında ya da gençlikle yaşlılık arasında da tezat unsurlar yaratılır. Osman Bey’le Şevket Bey arasında geçen bir konuşmada Şevket Bey, 'Nemide’yi göstererek dedi ki: Hayattan çıkmakta olan bir adamın kolundaki hayata yeni giren şu çocuk bir mezarın üstünde yeni açmış bir çiçeğe benzemiyor mu?" (s.75). Gençlik ve yaşlılık vurgusunun yapıldığı bu benzetme romanda öne çıkan temel tezatlardan biri olarak okura sunulur. Nahit'e göre evlenmek demek ölümle yeniden doğum arasında bir şeydir: “(...) evlenme bir yaşamanın üzerine kefen atıp başka bir yaşamanın örtüsünü açmaktır. Evlenme yeni bir hayatta yaşamak için eski hayatınızda ölmektir.” (s. 80). Yapıtın 88. sayfasında Nahit' in Nail'den nefret ettiği söylenir: "Nemide, saf, masum bir kız idi. Nahit ondan nefret etmiyordu. Yalnız Nail'den nefret ediyordu.” (s. 88). Aslında burada söylenen zıt anlamlıdır. Yazarın amacı nefret derken sevdiğini vurgulamaktadır. Zaten Nahit'in Nail'i sevdiği romanın genelinde görülür. Halit Ziya, Nahit üzerinden coşumculukta sıkça görülen zit unsurları eserinde bolca kullanmıştır. Bunlardan biri de Nahit'in Kanlıca'da kaldığı odayla ilgilidir. Nahit'in yattığı odanın manzarası çok

\footnotetext{
19 Bkz. S. 14

20 Bkz., s. 64.
} 
güzeldir: “(...) denize bakıyordu. Genç kız kıyının ışıklarını, denizin bir parçasını görüyordu.” (s. 83). Bu güzel tabloyla Nahit'in iç dünyası birbirinin zıttıdır: "Fakat Nahit bunların seyriyle uğraşmıyordu. Bahtsızlı̆̆ kararlaşmış, çarp ildiği felaketin altından kalkamayacağını iyice anlamış bir zavallı gibi açık açık ağlıyordu." (s. 83). Nahit'in yoksul olması ve Nail' in varsıl olması da bir başka zitlık unsurudur: Nahit daha bir çocuk iken Nail'in yanına gelir. Kalbindeki boşluğu Nail doldurur. "Tabiî olarak Nail'i sevmiş; çocukça bir bırakışla bütün umutlarını onun sevgisine, bütün hayallerini onun aşkına vermişti." (s. 84). Fakat zengin Nail, Nemide ile nişanlanınca yoksul ve çaresiz Nahit boşluğa düşer. "Onu başkasının kocası görmek, kendisinin yoksul olduğu mutluluktan başkasının faydalandığını görmek... oh!... bu olamaz... ama ne yapmalı,” (s. 84). Halit Ziya bu karşılaştırmayla zengin-yoksul tezatlığını da yansıtmış olur. Romandaki en trajik zıt unsur ise Şevket Bey'in evliliğinde ortaya çıkar. Evliliğinin en mutlu zamanlarını geçirirken eșinin hastalı̆̆ belirir: “( ...) en büyük mutluluğundan faydalanıyordu. Ama ne yazık ki, hayatta en az süren mutluluktur. Evlenmelerinden daha on gün geçmişti ki, genç kadın bir doktorun bakımına muhtaç olacak derecede hasta bulunuyordu." (s. 14). Bu hastalıktan sonra Şevket Bey'in yaşamı mutsuzluğa doğru gider.

\section{7. Ay ışı̆̆}

Nemide'de, ilk kez romantiklerde görülen ve 19. yüzyılın sonlarında sembolistlerde başat niteliklerden biri olan ay ışığı da göz ardı edilmemiştir. Halit Ziya ay ışığını iki kez kullanır: Bunlardan birincisi iki sevgilinin buluşması sırasında; diğeri ise Ay'dan söz ederken.

Nail, Nahit'le gece gizlice buluşurlar kendilerine ay ışı̆̆ğ eşlik eder: "Kıyıya kadar çıktılar, burada Nahit durdu, Nail ile karşı karşıya geldiler. Hafif bir ay ışığı geceyi donuk bir aydınlık içinde bırakmıştı." (s. 99). Bu ay ışı̆̆ı gizlice buluşan âşıkların yakalanmalarına neden olur: "Nemide kalkarak penceresinden baktı. Ay ışığının kumlar üzerinde çizdiği nurdan daireler içinde iki gölgenin kımıldadığını gördü; fakat bu iki gölge birbirine o kadar yapışmıştı ki; genç kız bir an için durakladı, biri iki görüyorum sandı." (s. 108). Nemide nişanlısının ay ışı̆̆ 1 altında Nahit'le aşk yaşadığını görünce gerçekleri kabullenmek istemez: "Kabil midir ki Nail şimdi, şu saatte Nahit'i ay ışı̆ğına karşı aşk şarkısıyla sarhoş etsin? Genç kız bir aralık Nail'in odasına gitmeyi tasarladi; fakat buna cesaret edemedi." (s. 108). Halit Ziya, ay ışığını doğrudan kullanmadığı zamanlarda onun doğmak üzere olduğunu hissettirir. Yapıtın ilerleyen sayfalarında kahramanlar sandalla geziye gitmeden önce "(...) ay daha doğmamış" (s. 142) denir ve denize açıldıklarında "Gökyüzünde sade birkaç yıldızın donuk ışıkları gülümsüyordu" (s. 143) ifadeleri kullanılarak ay ışığına dolaylı yönden değinilir.

Yapıtta yukarıda açıklananların dışında romantik akımın özelliklerinden sezgi, betimleme, hayvan sevgisi, merhamet, fedakârlık, iyi-kötü karşılaştırmasına da yer verilmiştir. Romantizm klasiklerin akılcılığını yadsımamakla birlikte aklın yanında “(...) estetik bir bakış açısı getirerek duygu ve sezgiyi ön plâna çıkarmıştır.'(Çetişli, 2006: 70). Böylece akıl-duygu-sezgi arasında bir uyuma ulaşırlar. Nemide ve Nail nişanlandıktan sonra işler bir ara yolunda gider; ama sonraki günlerde Nemide, Nail'le Nahit'in bakıştıklarını fark eder. “(...) bir türlü anlaşılamayan bakışları, onlarda okuduğu anlamları aklından geçiriyordu. Evet, gülü verirken Nail'in gözleri pek başka idi. (...) Nemide, Nail'in gözlerinin baktığı yere dikkat etmiş Nail hep Nahit'e bakıyordu.” (s. 107). Bu bakışlardan yola çıkan Nemide'nin sezgisi aldatıldığını ortaya çıkarır. Nemide çok kızar "(...) kanunu kırmak, yere çarpmak istemişti. Ama ses çıkarmamayı daha iyi bulmuştu, acı çekmekten garip bir zevk alıyordu.” (s. 107). Sezgisiyle aldatıldığını anlayan Nemide, önce sabreder. Çünkü romantizm akımının "Düşünüyorum ve hissediyorum, öyleyse varım!" ilkesinden hareket eden Nemide, hislerini başka örneklerle de teyit ettikten sonra ilişkisini bitirerek varlığını gösterir.

Romantiklerde hayvanlara da bir ilgi söz konusudur. Kantarcığlu bu ilgiyi "Duygu okulunun diğer bir özelliği de hayvanlara duyulan yakınlık ve sevginin bu okulu benimseyenler tarafindan ifade edilmesidir”'(Kantarcıoğlu, 2009: 97) diyerek açıklar. Halit Ziya'nın yapıtında hayvana yönelik ilgi de eksik bırakılmamıştır. Nemide'nin atı bulunmaktadır. Atına binmesi yasaklanınca çok üzülür: "Zavallı atımın her sabah beni bekleyerek kişnemesini, sabırsızlanarak ahırda tepindiğini işittikçe ağlayacağım gelirdi."(s. 95). Bu son örnek de gösteriyor ki, yazar romantizm akımının bütün özelliklerine ulaşmaya çalışır.

\section{Sonuç}

Türk edebiyatında Servet-i Fünûn romancısı olarak tanınan Halit Ziya, roman yazmaya İzmir'de yaşadığı yıllarda başlar. İlk ürünlerini de Hizmet gazetesinde tefrika ettirir. On sekiz, on dokuz yaşlarında gazetelerde romanlarının ciddiye alınıp okuyucuya ulaştırılması kendisi için büyük bir olanak olur. $\mathrm{Bu}$ olanağı çok iyi değerlendiren Halit Ziya, Sefile, Nemide ve Ferdi ve Şürekâsı gibi romanlara imza atar. İzmir'de tanınan bir yazar olan Uşaklıgil, İstanbul'a geçerek Servet-i Fünûn topluluğuna katılır. Tanzimatçılardan sonra gelen Servet-i Fünûncular, tiyatroyu bir kenara koyacak olursak başta roman ve 
hikâye olmak üzere birçok türde Batılı edebiyatçılara yakın yapıtlar ortaya koyarlar. Bu başarılarında da sanatı sanat için yapmaları, kendilerinden önce bir birikimin bulunması, yabancı dil bilmelerinin etkileri söz konusudur. Halit Ziya bu akım içerisinde Türk romanını çok ileri bir düzeye çıkaran Mai ve Siyah, Aşk-ı Memnu gibi yapıtlarını yazar.

Halit Ziya'nın ilk dönem romanlarından olan Nemide, 1889'da kitap olarak yayımlanır. Roman Halit Ziya'nın biçem aramaya devam ettiğini göstermektedir. Çünkü yazar Nemide'den kısa bir süre önce yazdığı Sefile'de realist akımın etkisinde kalırken bu yapıtında romantizmi benimser. Nemide, Tanzimat dönemi romanıyla Servet-i Fünûn dönemi romanı arasında bir geçiş görevi yapar. Bir yandan Tanzimat dönemi romanları gibi coşumculuk akımının etkisindeyken öte yandan da gerek roman tekniği gerekse bir mesaj vermekten uzak olması ve estetik kaygılarla yazılması nedeniyle Servet-i Fünûn roman anlayışına yaklaşır. Eserde imgeler ve semboller sanat için kullanılır. Merkezinde veremli bir genç kızın bulunduğu Nemide, üçlü bir aşk öyküsü etrafında şekillenir. Yazar etkisi altında kaldığı romantizm ekolünün başta marazilik olmak üzere birçok niteliğinden yararlanır. Kahramanlarda en çok görülen romantik özellikler; kaçış, hastalık, tezat ve ikilem ile gözyaşıdır. Nemide annesini hiç görmeden büyür. Kendisiyle birlikte büyüttüğ̈̈ verem yüzünden duygusal, hassas ve zayıf özelliklere sahiptir. Genellikle babasıyla, atıyla, bir şey öğrenirken ve gül bahçesinde geçirdiği zamanlarda mutlu olur. Amcasının oğlu Nail'le yaşadığı aşk, sonunun gelmesini hızlandırır. Öte yandan romanda Nemide'nin karşısına çıkarılan Nahit'in de annesi yoktur. Romantizm akımının doğal sonucu olarak Nahit de âşık olur, ağlar ve kaçmak ister. Yazar kaçış temasını romantiklere uygun olarak işler. Onların yaptığı gibi doğayı kullanır. Eserde kaçışla birlikte romantik akımda sıkça görülen iyi-kötü, ikilem, zıtlık gibi unsurlar başarılı bir biçimde kullanılmışlardır. Yazar, Nemide'nin babasını iyi gösterirken Nahit'in babasını kötü gösterir. Böylece iyi baba, kötü baba üzerinden zıtlık yaratmasını bilmiştir. Yine babasının yanında kalmayan Nahit'e teyzesi sahip çıkar. Bu da romandaki merhamet eksikliğini giderir. Öte yandan gül bahçesinde taze çiçeklerle uğraşan Nemide'nin hastalıklı olması ve her an ölecek olması da bir başka karşıtlık olarak ortaya çıkar yapıtta. Halit Ziya romantiklerde sıkça görülen olağanüstüye, hayale de yer vermiştir. Yapıtın son sayfasında Şevket Bey'in eşinin hayalinin gelmesi buna örnektir. Romantiklerde sıkça görülen yerellik ve ulusallık da yapıtta Nemide'nin belirli bir yaşa gelmesiyle ortaya çıkar. Toplumun gelenekleri göz önüne alınarak Nemide'nin tek başına erkeklerle konuşması ve ata binmesi yasaklanır. Öte yandan yine romantiklerde sıkça görülen kurallara karşı çıkma özelliği Nahit ve Nemide üzerinden verilir. Yazar bu kahramanları üzerinden toplumdaki evlilik kurumunu, eğitimdeki eşitsizliği sorgular. Bütün bu özellikleriyle Nemide, romantizm akımının gölgesinde yazılmış bir roman olarak Türk edebiyatındaki yerini alır.

\section{Kaynakça}

1. Akyüz, Kenan. (1995). Modern Türk Edebiyatının Ana Çizgileri. İstanbul: İnkılap Kitabevi.

2. Çetişli, İsmail. (2006). Bati Edebiyatında Edebî Akımlar. Ankara: Akçağ Yayınları.

3. Ercilasun, Bilge. (1994). Servet-i Fünûnda Edebî Tenkit. Ankara: MEB Yayınları.

4. Kantarcıŏlu, Sevim. (2009). Edebiyat Akımlarl/Platon'dan Derrida'ya. İstanbul: Paradigma Yayıncilik.

5. Karaalioğlu, Seyit Kemal. (1980). Edebiyat Akımlart. İstanbul: İnkılap ve Aka Kitabevleri.

6. Kudret, Cevdet. (1998). Türk Edebiyatında Hikâye ve Roman-i. İstanbul: İnkılap Yayınevi.

7. Robert P. Finn. (1984). Türk Romanı (İlk Dönem: 1872-1900). İstanbul: Bilgi Yayınevi.

8. Oktay, Ahmet. (1991). Zamanı Sorgulamak. İstanbul: Remzi Kitabevi.

9. Perin, Cevdet. (1942). Fransız Romantizmi. Ankara: DTCF Yayınları.

10. Tanpınar, Ahmet Hamdi. (2000). Edebiyat Üzerine Makaleler. İstanbul: Dergah Yayınları

11. Solak, Ömer. (2014). Kuramdan Uygulamaya Edebiyat Çalışmaları. Ankara: Ani Yayıncılık. 
12. Uşaklıgil, Halit Ziya. (1984). Nemide. İstanbul: İnkılap ve Aka Kitabevi.

13. Uşaklıgil, Halit Ziya. (2014). Kırk Yll. İstanbul: Özgür Yayınları.

14. Uşaklıgil, Halit Ziya. (1964). "Suut Kemal Yetkin’e Mektup”, Türk Dili Dergisi, Roman Özel Saylsı. Ankara: TDK Yayınları.

15. Yetkin, Suut Kemal. (1967). Edebiyatta Akmlar. İstanbul: Remzi Kitabevi.

16. Yücel, Tahsin. (1981). “Fransız Coşumculuğu”. Türk Dili Dergisi, Yazın Akımları Özel Sayısı. S. 349, Ankara: TDK Yayınları. 